\title{
Beyond Arab Spring: Societal Context and Prospects for a New Paradigm of Arab Management
}

\author{
Hala Abdulqader Sabri \\ Petra University- Amman, Jordan \\ habdulqader@uop.edu.jo
}

\begin{abstract}
This study investigates the defining characteristics of Arab management and takes into account the impact of societal and cultural factors on Arab managerial practices that provoked different opinions in the field of management thought. The proposition merits investigation because it takes place in the wake of the Arab Spring that emphasizes democratic change in Arab leadership styles and political systems. Hence, any evaluation of the underlying causes of this turmoil would recognize that a fundamental transformation in Arab management and leadership styles is also required; a transformation that creates an acceptance and eagerness to do things differently, and to keep pace with the rapidly developing societal and cultural environment. To achieve its objective, the study adopts a qualitative content analysis that incorporates the review and analysis of different studies that highlight features of Arab societal culture and the varied perspectives of Arab management styles. The study also considers some of the underlying causes and possible outcomes of the current Arab uprising as a possible basis for re-positioning Arab management in a new paradigm of management.
\end{abstract}

Keywords: Arab Spring, Societal Context, Arab Management, Paradigm.

\section{Introduction}

Research (Ali, 2009; and Sabri, 2004) indicates that Arab societies have a distinct cultural profile that surface in certain models of management. In this context, authors illustrated a model of Arab management that mostly originates in the tribal culture and provided a 'Bedou-cracy' (Abdel-Khaleq, 1984) and 'Sheikho-cracy' (Al-Kubaisy, 1985) models that manifest in traditional bureaucratic design and prevailing power culture. These tribal models demonstrate Arab management practices as a mix of hierarchical authority, rules and regulations contingent on personality and power of individuals who make them, subordination of efficiency to personal relations and connections, uncertainty in decision making, nepotism and a generally patriarchal approach. Other research, on the other hand, (Khadra, 1990), explored Arab management from an Islamic perspective and introduced a 'Prophetic-Caliphate' model of Arab management in which the leader is a 'great man' who follows Islamic rules and displays a remarkable confidence in his behavior and action by being compassionate, attentive, and flexible leader. Lately, much of the research (House et al., 2004; Hofstede, 2010; Hickson \& Pugh, 2002; Sabri, 2007) employed a cross-cultural comparative perspective in examining Arab managerial and leadership styles, and observed that Arab executives face many organizational and managerial problems, which represent critical challenges in their quest to enhance their competitive advantage in the global work environment. These different views of Arab management will be the focus of this study. Specifically, the study investigates Arab management practices as explored within three perspectives: the tribal; the Islamic, and the current. In addition, the study takes into account the recent Arab Spring that calls for reform in the leadership and political systems, as a possible basis for re-positioning and transforming Arab managerial styles into a new paradigm of management.

Purpose and Significance of the Study: In spite of increasing interests in cross-cultural research, the study of the culture and behaviors of management and business in the contemporary Arab world is a relatively recent incidence (Weir, 2005). Hitti (1996) argued, however, that the point of how much contemporary Arab culture remains traditional is a question that should constantly be tested because cultural values, which have been largely assumed to foster it, are changing. This study responds to this proposition and provides an analysis of the driving forces that advance the emergence of models of Arab management. The study is important and timely as it takes place in the wake of the remarkable Arab Spring that draws the attention to major cultural and political transformations in the Arab world. This Arab Spring, many deem, is empowering, and has shifted the power scale towards Arab citizens away from a rigid form of governance. Hence, the author believes that it is likely to spill over and influence many other aspects of Arab societies, among of which are Arab management and leadership styles. 
Moreover, as the development prospects of Arab countries are increasingly linked to their leadership capabilities and the quality of their work forces, addressing the issue becomes a critical challenge for Arab organizations to enhance their competitive advantage in the global work environment.

\section{Methodology}

The choice of Arab culture and Arab management as a research area was shaped by a combination of personal interest, experience and opportunity. Zinn (1979) suggests that a researcher working within his/her own culture is able to interpret the meaning because of familiarity with that culture and an understanding of how events may be perceived. Temple (1997: 607), argues also that "the researcher's identity and experience are critical to the success of the research. The researchers' intellectual autobiography influences what they know and their experience influences what they research." Hathaway (1995) maintains, however, that decisions about which kind of research method to use may be based on the researcher's own experience and preference, the population being researched, the proposed audience for findings, time, money and other resources available. Therefore, to gain a better understanding, through in-depth exploration and description of the Arab culture and management, the researcher believes that a qualitative content analysis is the most appropriate to use (Myers, 2000). Thus, the research methodology encompasses the review of different studies that highlight features of Arab culture and its reflections on Arab management styles. It should be noted however, that the author refers to the Arabs as one nation, or one integrated society, which shares some common characteristics: the environment, the people, the language, the religion, the social structure and the culture but lacks a unified political system (Barakat, 2008).

\section{Arab Management in Perspective}

Arab Identity, Society and Culture: Touma (1996) considers an 'Arab' the one who is a national of an Arab state, has command of the Arabic language, and possesses a fundamental knowledge of Arab tradition, customs, and political and social systems of the culture. Patai (2002), Lewis (1993) and Resto (2003) argue that the original Arabs are the Bedouins inhabiting the Arabian Peninsula and the Syrian Desert. Patai (2002) deems that in the first historical appearance of the Arabs they were camel-herding desert Bedouins, and hence, throughout centuries, the association between Arabs and the desert has never ceased. However, after the foundation of Islam the term 'Arab' came to denote all the peoples who, after having been converted to Islam, gave up their ancestral languages and adopted Arabic instead. Simultaneously, the Arab conquerors of the new lands lost their originally tribal character, settled down, and became town inhabitants (Patai, 2002). However, Ibn Khaldun (1969), distinguished between sedentary Muslims who used to be nomadic Arabs and the Bedouin nomadic Arabs of the desert. He used the term "formerly-nomadic" Arabs and referred to sedentary Muslims by the region or city they lived in, as Egyptians, Spaniards and Yemenis.

Zahra (1980), Almaney (1981), Ali (1996) and Hickson and Pugh (2002), viewed the Arab's cultural patterns having their roots in the Bedouin origins and primitive tribes. Other research on the Arab world observe 'language and religion' as distinguishing characteristics of Arab culture and society. Weir (2005) argues, for instance, that Arab societal culture is a major influence within the Arab region, though it exhibits as much internal diversity in attitudes, behavior and systems of government and administration. This is largely due to the dominance of one Arabic language and a unifying religion, Islam, which accounts for approximately twenty percent of the world's believers. Sulaiman (2007) contends also that the Arabs are defined by their culture, not by race; and their culture is defined by Arabism and Islam. The Arab identity, as such, is a culturally defined identity, which means being an Arab is being someone whose mother culture, or dominant culture, is Arabism. Sulaiman (2007) adds also that being an Arab does not contradict with being non-Muslim or non-Semitic or not being a citizen of an Arab state.

Ali (1993) argues, however, that before the birth of modern Arab nations, Arab countries have been subjected to external and internal sources of influence resulting in cultural discontinuity that broke the link of Arab generations with their cultural heritage and principles and affected negatively the development of Arab management thinking, causing the breakdown of Arab stamina and morale. Based on his empirical cross-cultural research on work values, Hofstede (2001) categorized the Arab societies with high inclination to power and authority (large power-distance), high tendency to avoiding risk and uncertainty (uncertainty avoidance), domination of males over females (masculinity) and collectivism 
manifested in a close long-term commitment and loyalty to the family and the tribe that over-ride most other societal rules.

The high Power Distance in Arab societies is an indicative of inequality of power and wealth within the society. The head of family has absolute power and is responsible for the family's life and well-being; hence, all family members must obey and respect his wishes. Subordination of children to the father, the younger to the older, and females to males is also common in Arab culture. Children are also brought up to be obedient and submissive rather than autonomous which instill in them a sense of dependency, lack of self reliance, and weakness of character (Sharabi, 1990). Therefore, allegiance in Arab countries extends to the societal and political systems through the patronage structure. However, Hofstede (2004) argues that when power and rules are combined, they create a situation where leaders have virtually ultimate authority, and the rules, laws and regulations developed by those in power reinforce their own leadership and control. Therefore, it is not unusual for new leadership to arise from armed insurrection, rather than from diplomatic or democratic change.

\section{Arab Management Approaches}

Weir (2005) believes that there is considerable evidence that management in the Arab world is unique and fits its own mold. In addition to the American, European and Japanese cultures of management, Weir (1998 \& 2001) identified a 'fourth paradigm', as a guide to the study of management in Arab countries. He illustrated the key components of this model as fairly rooted in the nature of Islam and social and political life in the Arab world. He believes, therefore, that Western ideas of democracy, equality and participation may be somewhat alien to the Arab social behavior in which kinship, local, regional and clan loyalties are significant. Hickson and Pugh (2002) demonstrated also that the history of the Arabs exerted four primary influences over Arabs in general and Arab management in particular: the Bedouin and wider tribal inheritance, Islam, foreign rule and the oil thirsty West. Ali (2009) also found that the major influences associated with the study of Arab management are: language, history, religion, traditional tribal values and external forces.

However, Dadfar (1993) argued that Arab management systems should be explored within the predominant values adopted from 'tribalism', Islam and Westernization. In this context, scholars undertook the study of Arab management within different approaches: the tribal approach that results in traditional bureaucratic design and prevailing power culture (Al-Kubaisy, 1985); the 'prophetic-caliphate' approach which undertakes an Islamic viewpoint (Khadra, 1990); and finally the current approach that adopts a cross-cultural perspective in analyzing Arab management and leadership styles (House et al., 2004; Hofstede, 2010; Hickson \& Pugh, 2002; Sabri, 2007).

The Tribal Approach: The early Arabs, before the emergence of Islam, valued the work in trade and commerce. Their life within the Bedouin environment emphasized patience, group cohesion, cooperation and allegiance within their same tribe, therefore, all relations and loyalties are centered on family or tribes units (Sharabi, 1988). The family patriarch has absolute power in the family and is responsible for the family's life and well-being. In return all members of the family must obey him and respect his wishes. Face-saving and status-consciousness are often important values within tribal culture (Gregg, 2005). In relation to others, they valued competition and revenge but they also valued hospitality and generosity (Almaney, 1981). However, Armajani and Ricks (1986) indicated that after the emergence of 'Islam', the Semitic tribes of Arabia were unified and conquered non-Arab countries. The Arabs linked the process of Islamization by mixing Bedouin norms and values with the Islamic ones and introduced them to the conquered nations.

Dadfar (1993) believes that 'tribalism' is integrated into the political and economic systems of Arab countries. Despite political constraints, business organizations across the Arab nations have flourished and capitalized upon the family, the tribe and the individual. The 'tribal' orientation can be explored in the sense of family commitment and loyalty to tribe, over centralization of power in the hand of the tribe's chief, relationship with others, bravery, rivalry, male domination, love of prestige by social class, and formality. Al- Kubaisy (1985) and Abdel-Khaleq (1984) used Arab tribal orientation to introduce 'Sheikho-cracy' and 'Bedou-cracy' models, as a product of the interaction of bureaucratic and sheikh orientations and behaviors. These models are reflected in hierarchical authority, rules and regulations contingent on the personality and power of the individuals who make them, subordination of efficiency to 
human relations, indecisiveness in decision making, and a generally patriarchal approach. Nepotism is also often evident in assigning relatives or clan members to senior positions in organizations and in the government.

The Islamic Approach: The emergence of Islam represented the establishment of a new community where many of the concepts, values, and conditions of the Arabs were radically transformed. While still emphasizing the importance of patience and group unity, it was made clear that these values should be applied among all believers in the society, and not only within the individual tribal structure. Hence, Islam's major achievement was uniting the Arabs into a single dynamic nation. Nowadays, almost eighty percent of the Arabs are Muslims (Ali, 1996). Islam is a large system containing rules for a complete way of life. It dictates family life, the relationships of an individual to his fellow citizens, attitudes towards others, and the responsibility of the individuals within the society. Islam has also provided dominant rules for economic activities, tasks and responsibilities of governors and so on. The internalization of Islamic concepts strengthens the qualities of honesty, trust, solidarity, loyalty and flexibility. Weir (2000) asserts that the growth of the Islamic movement in the Arab world has had a widespread effect on philosophy, education and legal thinking within the Arab countries and has started to have an impact on business and management. Amongst the fastest growing institutions are the Islamic Banks which promote an Islamic philosophy and base their practice on these principles.

Comparing the concepts of management in Islam to the Western one, Al-Faleh and Haydel (1994) recognized that management concepts in Islamic civilization differ from Western ones. Islamic concepts embody such relationships in the light of the Holy Quran and the teachings of Prophet Mohammed. They assert, therefore, that Islamic management is self management and permeates all aspects of organization. In Islam, the best managers are those who are concerned with the affairs of the material world and the Hereafter. This stress, on both the spiritual and material aspects of life, is a unique characteristic of Islamic management. Khadra (1990) explored Arab management from an Islamic perspective and introduced a 'Prophetic-Caliphate' model. In this model he referred to the Islamic manager as the 'great man' who follows Islamic rules and suggested that the role and quality of the individual leader take on an added value. If the leader happens to be a visionary person then a prophetic model emerges, a compassionate, attentive, flexible leader, who displays a remarkable confidence in his behavior and action.

Barakat (2008) acknowledges, however, that although the Islamic religion is the most important aspect in the Arab culture, but the Islamic religious system is often used to legitimize the tribal values of leadership. In this sense, Islam is used to protect family interests and benefits and shield tribal values rather than as a pure belief system. Dadfar (1990) also believes that even though Islam is against tribalism and preIslamic values, the Arabs have skillfully blended the Bedouins' values with the Islamic ones that it is difficult to draw a clear borderline between Islamic and pre-Islamic Arab values. To a large extent, Islamic values exist only in theory and literature but not in practice. Yet, Ali (1996) argues that the 'Sheikhocracy' model is inconsistent with Islamic teachings. Assigning relatives or clan members to senior positions in organizations and in the government, runs contrary to the spirit of Islam.

The Current Approach: Recent studies have employed a cross-cultural comparative approach in studying Arab management styles and practices (House et al., 2004; Hofstede, 2010; Hickson \& Pugh, 2002; Sabri, 2004 \& 2007). Sidani (2006) argues, however, that the current work values in the Arab culture cannot be categorized in one cell because the Arab society has lost its homogeneity as there are sharp current differences across the Arab countries in terms of wealth, economies, political systems, natural and human resources. Yet, Ali (2009) contends that contemporary management theories and practices are relatively new to the Arab business environment as Arab countries are faced with 'late development effect' (Dore, 1973). That is late developing countries will show in their organizations progressive forms of bureaucracy from the beginning. Therefore, Western bureaucratic forms and principles were copied in Arab countries in organizing the armed forces and public enterprises during the early phase of evolution. However, chain of command, scalar principles and division of labor are not strictly observed in Arab organizations as they are in Western bureaucracies. Sabri (2011) found, for instance, that Jordanian organizations utilize more bureaucracy than British and Swedish organizations, and employ more power oriented culture than American and South African organizations (Sabri, 2004). 
Ali (1996) believes that major Arab businesses and institutions imitate foreign procedures and organizational structures and have failed to recognize that adaptability of management principles and concepts, demands selectivity and attentiveness to their unique culture. Cunningham and Sarayrah (1993) maintain also that the Arab nations have imported modern laws, rules and structures but old practices and customs stay behind. Moreover, Attiyeh (1993) argues that attitudes and behavior in the Arab world are influenced by rulers and the ruling elite, government bureaucracies, legal systems, educational institutions and mass media. Hofstede $(1984,2001 \& 2004)$ found that high power orientation of Arab culture is manifested in a strong tendency for authoritative and paternalistic styles of management resulting in high centralization of decision-making. In Arab organizations top executives demand complete submission of their employees who, in return do not take initiative and expect to be told what to do. Besides, as a mean to control the uncertainty, Arab managers adopt a highly personalized management style, and assert their reliance on rules and regulations to avoid unpredictable situations. However, they assign duties according to their personal judgment calling on rules and procedures that are generally neglected, as a protective tactic to reinforce their power (Sabri, 2004). Sulaiman (2007) also believes that Arab managers have been more prone to follow the trend of the day than to educate, and lead.

Moreover, in Arab organizations management of groups and relationship prevails over task stemming from their collectivist orientation (Hofstede, 2010). Employer-employee relationship is perceived like a family link, hence, allegiance to company growth is secondary to that of the family and it is the duty of everyone to take care of both family and tribe's members whenever he is assigned to a high position either in private or public organizations. The "GLOBE" studies (Dorfman \& House, 2004), found also that effective Arab managers are self-protective, self-centered, status-conscious, keen on face-saving, and rely on conflict induction and procedures. Other research (Al-Hegelan and Palmer, 1985; and Sabri, 2004) implied that Arab managers are reluctant to delegate authority; prefer stable lifestyle over rewarding but challenging work; and give priority to friendships and personal considerations over organizational goals and performance.

As a result different researchers point to several areas of concern facing Arab organizations: massive expansion in administrative size (Al-Saigh, 1986); over-centralization (Khadra, 1990); inadequate coordination (Nonneman, 1988); inadequate concern for quality; low concern for development and innovation (Zahlan, 1981); low pay of employees especially in the public sector; and finally, neglect of written rules and procedures that usually exist but are not used in practice and are mostly neglected (Dadfar, 1990). 'Wasta' (means mediation), is also a current problem facing Arab management as it is practiced in social relations and organization by referring to the powerful people in society. It is valued for resolving conflicts, obtaining benefits or to speeding up one's paperwork by a third party (Cunningham and Sarayrah, 1993).

Beyond Arab Spring: The Future of Arab Management: Undoubtedly, 2011 is a remarkable year with young Arab people incited an uprising because they are unable to enjoy life's full opportunities and rewards, in terms of education, work, income and material well-being (Khouri, 2011). Although at the beginning many could not predict the Arab youth's massive protests, but while 2011 is coming to fold it can be said with certainty that there is no going back as the Arab Spring has restored Arab self-esteem and united the people in the understanding that true security is based on 'human dignity' and 'freedom' (Bin Talal, 2011). Therefore, the author believes that the evaluation of the underlying causes of this unprecedented turmoil would recognize that any fundamental change in Arab leadership or political systems will spill over and influence many other aspects of Arab societies, among of which Arab management and leadership styles that are required to embrace the required transformation and keep pace with the rapidly developing societal and cultural environment.

Underlying Causes of the Arab Spring: Different scholars deem that different important political, cultural, economic and technological reasons stand behind the Arab youth uprising. A recent poll of young Arabs throughout the Middle East and North Africa, by the Gallup organization and Silatech foundation in Qatar, provided extraordinary insight into two important backdrops to the revolt: young people are strongly dissatisfied with their national conditions and personal prospects, and the concerns and fears of young Arabs are shared by adults across the region (The Silatech Index, 2010). Khouri (2011) argues, also that 'humiliation' and 'legitimacy' are the most important factors that explain why the Arab region has erupted, and what needs to be done to satisfy popular demands. Khouri explains that hundreds of 
millions of Arabs feel they have been denied their human and citizenship rights as a result of decades of socioeconomic stresses and political deprivations. These include minor and large-scale corruption; police brutality; abuse of power; favoritism; unemployment; poor wages; unequal opportunities; inefficient or nonexistent public services; lack of freedom of expression and association; state control of media, culture and education; and many other dimensions of the modern Arab security state. At the same time, ordinary men and women in countries across the region have seen small groups of families in the ruling elite grow fabulously rich simply because of their connections.

Suleiman (2007) contends also that lack of freedom, weakness of the educational system, authoritarian governance, and the foreign influence backing traditional national regimes in upsetting democratic and progressive evolution, among many others, are significant reasons for why has the Arab nation lagged behind the other nations in the modern era. Moreover, Sulaiman (2007) indicates that the severe gap between a proud, rich past and a fragmented and disrupted present produced deep frustration in the Arab consciousness. With the advent of oil wealth early in the second half of the twentieth century, opportunities arose before the Arabs to democratize, and invest substantially in human development across their homeland. But opportunities came and went, withering away in the face of narrow selfinterest, inter-state quarrels, inadequate understanding of the modern world, and a less interest at the leadership level in the welfare and destiny of the nation as a whole.

Moreover, the technological communication, through Internet and social media has hastened the process of globalization and worldwide relations and harmonized the manner in which individuals and organizations operate worldwide, creating challenges arising from different styles of communication and introduced a powerful new dimension of transparency to global politics from which no country, under any political system, is immune. Cambieri (2011) believes that one major outcome of this technological communication is that it has changed the face of the Arab world as the rise of the Internet and social media allowed those in Arab nations to learn more about how the rest of the world operated both historically and in real time.

Prospects for a New Paradigm of Arab Management: The reviewed literature on Arab management in this study indicates that the Arab society has its own unique social and cultural environment which plays a major role in molding its organizational processes and managerial systems. However, Fernandez et al., (1997) argue that when the political, societal and economic environments change, people's cultural values also change. That is, societal changes, such as economic growth, education, and democracy, could affect work-related dimensions; and that significant changes in cultural values occur as external environmental factors shape a society. This change is evident as recent events have shown that Arab youths make their own history, and are capable of controlling their own destinies. Arab youths have also challenged, to a great extent, the argument that Arab populations have an expectation and acceptance that leaders will separate themselves from the group and this condition is not necessarily subverted upon the population, but rather accepted by the society as their cultural heritage (Hofstede, 2001). With the young Arabs taking part in political and economic transformation, it can be said that Arab society is in transition, discarding its old tribal and traditionalist beliefs to move towards the basis for a more modern economy (Ali, 2005).

The new millennial generation in the Arab world may have been influenced by tribalism and historical events, but these traditional sources of primary socialization may have had less impact on those individuals because many of them may have been exposed to alternative sources of mental programming or socialization, through higher education, new modes of communication, overseas experience, the media and employment in foreign corporations. This line of argument recognizes the possibility that the classification of the Arab culture may fail to reflect an accurate picture of the effects of the mental programming or processes of secondary socialization that many Arab youths are exposed to. The author believes that the current political, cultural and societal transformations in the Arab world is expected to spill over and infuse a transformation in Arab managerial behaviors which have special significance to Arab countries, as they are transiting towards new paradigms of leadership and systems consistent with the demands of the Arab Spring. This new paradigm of management demands that successful leaders and managers in Arab organizations need to adapt and move in harmony with the current changing environment in their countries that is based on consultation, participation, creativity, diffusion of knowledge, and providing equal promotion opportunities. 
It is also suggested that as Islam plays a major role in Arab culture and the belief of the Arab people (Khalid, 1977) as studies show that it ranks higher than family, citizenship, national origin, and political ideology (Farah, 1978 and Farah \& Al-Salem, 1980), utilizing Arab Islamic culture in solving organizational problems can serve as a legitimate source of work ethics in the new paradigm of Arab management. Khouri (2011) believes that the two most critical elements of legitimate governance systems in Arab-Islamic lands are accountability and a sense of justice, or equity. Constitutions, parliaments, electoral laws and other mechanisms can be devised in many forms, insinuated by Arabism, Islamism, tribalism, cosmopolitanism, but above all, they must be legitimate in the eyes of their people if the societies are finally to emerge from the dark tunnel of the security state and its corrupting heritage (Khouri, 2011).

\section{Conclusion}

The Arab Spring is now synonymous in the eyes of the world, and, most importantly, in the eyes of the Arab people. Yet, the success of the Arab Spring most likely rests, on the long run, on achieving democratic political reform and economic stability and sustainability. Most importantly, the Arab uprising has shown that conceptions of Arab culture are heavily based on personal observations and untested assumptions that traditional culture is the sole or major source of attitudes and values (Yassin, 1983). The validity of these assumptions must be challenged, because cultural values which have been largely assumed to foster it are changing

\section{References}

Abdel-Khaliq, N. (1984). Environmental Dimensions of Bureaucracy in Kuwait. Studies in the Gulf and Arabia, 10 (38), 13-65.

Ali, A. (2009). Business and Management Environment in Saudi Arabia: Challenges And Opportunities for Multinational Corporations, New York: Routledge

Ali, A. (2005). Islamic Perspectives on Management and Organization. Edward Elgar: Cheltenham.

Ali, A. (1996). Cultural Discontinuity and Arab Management Thoughts. International Studies of Management and Organization, 25 (3), 7-30.

Ali, A. (1993). A Cross-National Perspective on Managerial Problems in a Non-Western Country. A Paper Presented at the First Arab Management Conference, Bradford Management Centre, Bradford, July 6-8.

Al-Faleh, M. \& Haydel, B. (1994). Islamic Management and Western Management Thought: A Comparative Study. Business Research Yearbook, 1, 185-191.

Al -Hegelan, H. \& Palmer, M. (1985). Bureaucracy and Development in Saudi Arabia. Middle Eastern Journal, 39, 48-59.

Al-Kubaisy, A. (1985). Theory and Practice of Administrative Development in a New Nation. Dissertation Abstracts I, (A32), 5873 - A.

Almaney, A. J. (1981). Cultural traits of the Arabs: Growing Interest for International Management. Management International Review, 21 (3), 10-18.

Armajani, Y. \& Ricks, T. M (1986). Middle East: Past and Present (2nd ed.), Prentice-Hall Inc.

Al Saigh, N. N. (1986). Public Administration and Reform in the Arab World: Realities and Aspirations. In Al-Saigh, N. N. (ed.), Administrative Reform in the Arab World: Readings. Amman: Arab Organization for Administrative Sciences.

Attiyeh, H. (1993). Roots of Organization and Management Problems in Arab Countries: Cultural or Otherwise? A Paper Presented at the First Arab Management Conference, Bradford Management Center, Bradford, July 6-8.

Barakat, H. (2008). The Modern Arab Society: An Experimental, Social Research (10 ${ }^{\text {th }}$ ed.), Beirut: Center for Arab Unity Studies.

Bin Talal, E. H. (2011). February 16). Don't Fear the Middle East New Wave. The Guardian Newspaper. Online http://www.guardian.co.uk/commentisfree /2011 /Feb/16/dont-fear-middle-east-newwave.

Cambieri, G. (2011). May 28). Arab Spring Can Reverse Middle East's False Stigmas. Business Because. Online http://www.businessbecause.com/mba-2011/arab-spring-can-reverse-middle-eastsfalse-stigmas-article8828.htm.

Christopher J. R., Jamal A. K. \& Al-Habib, M. (2002). The Relationship between Arab Values and Work Beliefs: An Exploratory Examination. Thunderbird International Business Review, 44 (5), 583-601. 
Cunnigham, B. \& Sarayrah, Y. (1993). WAST: The Hidden Force in Middle Eastern Society, Praeger.

Dadfar, H. (1990). Industrial Buying Behavior in the Middle-East: A Cross-National Study. Doctoral Dissertation, Linkoping University.

Dadfar, H. (1993). In Search of Arab Management Direction and Identity. A Paper Presented at the First Arab Management Conference. University of Bradford, Bradford, July 6-8.

Dore, R. (1973). British Factory-Japanese Factory. London: George Allen and Unwin.

Dorfman, P. W. \& House, R. J. (2004). Cultural Influence on Organizational Leadership: Literature Review. Theoretical Rationale and GLOBE project goals, In R. J. House, P. J. Hanges, and M. Javidan. P. W, Dorfman, and V. Gupta (eds.). Culture, Leadership, and Organizations: The GLOBE Study of 62 Societies (51-73), Thousand Oaks, CA: Sage Publications.

Farah, T. E. (1978). Group Affiliations of University Students in the Arab Middle East (Kuwait). The Journal of Social Psychology, 106, 161-165.

Farah, T. E. \& Al-Salem, F. (1980). Group Affiliations of Children in the Arab Middle East (Kuwait), The Journal of Social Psychology, 111, 141-142.

Fernandez, D. R., Carlson, D. S., Stepina, L. P. \& Nicholson, J. D. (1997). Hofstede's Country Classification 25 Years Later. The Journal of Social Psychology, 137(1), 43-54.

Gregg, G. S. (2005). The Middle East: A Cultural Psychology. Oxford: Oxford University Press

Hathaway, R. (1995). Assumptions Underlying Quantitative and Qualitative Research: Implications for Institutional Research. Research in Higher Education, 36 (5), 535-562.

Hickson, D. \& Pugh, D. S. (2002). Management Worldwide: The Impact of Societal Culture on Organizations around the Globe ( $2^{\text {nd }}$ ed.), London: Penguin Books.

Hitti, P. K. (1996). The Arabs: A Short Story, Washington D.C.: Regnery Gateway.

Hofstede, G. (2010). Greet Hofstede Cultural Dimensions, Online http://www.geert-hofstede. com/hofstede_arab_world.shtml.

Hofstede, G. (2004). Cultures and Organizations: Software for the Mind (2nd ed.), London: McGraw- Hill.

Hofstede, G. (2001). Cultural Consequences: Comparing Values, Behaviors, Institutions and Organizations across Nations ( $2^{\text {nd }}$ ed.), Thousand Oaks, CA: Sage Publications.

Hofstede, G. (1984). Culture's Consequences: International Differences in Work-Related Values, London: Sage Publication.

House, R. J., Hanges, P. J., Javidan, M., Dorfman, P. W. \& Gupta, V. (eds.) (2004). Leadership, Culture, and Organizations: The GLOBE Study of 62 Societies. Thousand Oaks, CA: Sage Publications.

Ibn Khadlun, A. A. (1969). The Muqaddimah, an Introduction to History. Editors: Franz Rosenthal \& N.J. Dawood, translated by Franz Rosenthal, Abridged Edition, NJ: Princeton University Press.

Khadra, B. (1990). The Prophetic-Caliphate Model of Leadership. Studies of Management and Organization, 20 (3), 37-52.

Khalid, M. (1977). The Socio-cultural Determinants of Arab Diplomacy. In Atiyeh, G. (ed.) Arab and American Cultures. Washington, DC: American Enterprise Institute for Public Policy Research.

Khouri, R. (2011, September 12). The Arab Awakening. Op-Ed, Agence Global, Belfer Center Programs or Projects, The Dubai Initiative. Online http://belfercenter. ksg. harvard.edu/publication/21294/arab_awakening.html?breadcrumb=\%2Fpublication\%2F20564 \%2Fguide_to_the_young_arab_world.

Lewis, B. (1993). The Arabs in History. Oxford University Press, USA.

Myers, M. (2000). Qualitative Research and the Generalizability Question: Standing Firm with Proteus. The Qualitative Report, 4 (3/4). Online http://www.nova. edu/ ssss/ QR/ Myers.html.

Nonneman, G. (1988). Administration and Aid in the Middle East. London: Routledge.

Patai, R. (2002). The Arab Mind (Revised ed.). Hatherleigh Press.

Retsö, J. (2003). The Arabs in Antiquity: Their History from the Assyrians to the Umayyad. Routledge, 105, $119,125-127$

Sabri, H. (2011). Do Power Distance and Uncertainty Avoidance determine Organizational Structure: A Culture Bound Versus Culture Free Debate? A Paper Presented at Common Ground's 10th International Conference on "Knowledge, Culture and Management", Madrid-Spain, 15-17 June 2011. Online http://www.youtube. com/watch?v=fcdZ2y9ZVts\&feature=mfu_in_order\&list=UL.

Sabri, H. (2007). Jordanian Managers' Leadership Styles in Comparison with the International Air Transport Association (IATA) and Prospects for Knowledge Management in Jordan, International Journal of Commerce and Management, 17, (1/2), Emerald Group Publishing-USA.

Sabri, H. (2004). Socio-Cultural Values and Organizational Culture, In K. Becker, Islam and Business, New Jersey: Haworth Press: 123-145.

Sharabi, H. (1988). Nepotriarchy: A Theory of Distorted Change in Arab Society. Oxford University Press. 
Sharabi, H. (1990). Introduction to Study the Arab Society (4th ed.), Beirut: Dar Al Talaiah.

Sidani, Y. M. (2006). Work Values in the Arab Culture. Advances in Global Business Research, Proceedings of the 2006 Academy of Global Business Advancement Third World Congress, Kuala Lumpur, Malaysia, January, 2006. Online http://aub. academia.edu/YusufSidani/Papers/198689/ Work _Values_in_the_Arab_Culture.

The Silatech Index (2010). Voices of Young Arabs. The Silatech Foundation and Gallup Organization, Online http://sas-origin. onstreammedia.com/origin/ gallupinc/ media/poll/ pdf/ Silatech.Report.2010.Nov.pdf.

Sulaiman, S. J. (2007). The Arab Identity. Al-Hewar, the Arab American Dialogue, Winter, 2007, Online www.alhewar.net/Basket/Sadek_Sulaiman-ARAB_IDENTITY.

Temple, B. (1997). Watch Your Tongue: Issues in Translation and Cross-Cultural Research. Sociology, 31 (3), 607-18.

Touma, H. H. (1996). The Music of the Arabs. Portland, Oregon: Amadeus P.

Weir, D. T. H. (2005). The Arab as the "dangerous other"? Beyond Orientalism, Beyond Post-Colonialism. A Paper Presented at the Track on Post-Colonialism Critical Management Conference Cambridge 2005, Online http://www.mngt. waikato.ac.nz/ ejrot/ cmsconference/2005/proceedings/ post colonialism/ Weir.pdf.

Weir, D. T. H. (2000). Management in the Arab World, In Warner, M. (ed.) Management in Emerging Countries: Regional Encyclopedia of Business and Management. London: Business Press/Thomson Learning.

Weir, D. T. H. (1998). The Fourth Paradigm, In A.A. Shamali and J. Denton (eds.), Business Management in the Arab Middle East. Kuwait: Gulf Management Centre.

Weir, D. T. H. (2001). Management in the Arab World: A Fourth Paradigm. A Paper Presented at the First European Academy of Management Conference (April), Barcelona, Spain.

Yassin, S. (1983). Administrative Objectives for Development Administration. Administrative Science Quarterly. 9, 91-108.

Zahlan, A. (1981). The Arab Brain Drain, London: Ithaca Press.

Zahra, S. (1980). Egyptian Management at the Cross-roads. Management International Review, 20(3), 118124.

Zinn, M. B. (1979). Field Research in Minority Communities: Ethical, Methodological and Political Observation by an Insider. Social Problems, 27 (2), 209-219. 